\title{
BACTERIA AND INFLAMMATORY RESPONSE IN THE UTERUS OF BITCHES AFTER ARTIFICIAL INSEMINATION
}

\author{
Ana Paula Coelho Ribeiro ${ }^{1}$, Wilter Ricardo Russiano Vicente ${ }^{2}$, \\ Ivo Walter dos Santos ${ }^{3}$, Maricy Ferreira Apparício², Roberta Carareto', \\ Caroline Peters Pigatto ${ }^{1}$
}

\footnotetext{
1 Universidade Federal do Tocantins - apcribeiro@uft.edu.br

2 Universidade Estadual Paulista - Campus de Jaboticabal

3 Universidade Federal do Paraná - Câmpus de Palotina
}

\begin{abstract}
The present study aimed to obtain information about the uterine inflammatory response (number of polymorphonuclear neutrophilic granulocytes - PMNs) in bitches after artificial insemination $(\mathrm{Al})$ and identify the uterine microflora present after the following treatments: insemination using semen with extender $(n=6)$, insemination with fresh semen $(n=6)$ and no inseminated $(n=6)$. The percentage of PMNs on the endometrial surface and within histological sections was evaluated together with the presence of aerobic bacteria in the uterine lumen. For endometrial cytology, there was no significative difference on the number of inflammatory cells between bitches not inseminated (3.05 $\pm 1.74 \mathrm{PMNs})$ and those inseminated with fresh semen (3.55 $\pm 1.51 \mathrm{PMNs}$ ); There was a significative difference in both groups compared to the inseminated with semen plus extender $(7.80 \pm 1.67 \mathrm{PMNs})(\mathrm{p}<0.05)$. Histology showed that there was no significative difference on the number of inflammatory cells between bitches not inseminated ( $87.72 \pm 35.2 \mathrm{PMNs})$ and those inseminated with fresh semen (122.97 $\pm 43.31 \mathrm{PMNs})$; however, it was observed differences in both groups compared to those inseminated with semen plus extender $(171.94 \pm 42.74$ PMNs) $(p<0.05)$. Eight animals, randomly distributed in the groups, showed the presence of Staphylococcus sp and Proteus sp., in the microbiological exam. The extender for semen, with Tris, is a potent inducer of uterine inflammation, and positive uterine cultures may be obtained during estrus without inflammation or uterine infection.
\end{abstract}

Key words: bitch; inflammation; reproduction; semen

\section{BACTÉRIAS E RESPOSTA INFLAMATÓRIA NO ÚTERO DE CADELAS, APÓS INSEMINAÇÃO ARTIFICIAL}

RESUMO: O presente estudo objetivou caracterizar a reação inflamatória aguda uterina em cadelas submetidas à inseminação artificial (IA), e identificar a flora bacteriana presente após os seguintes tratamentos: inseminação com sêmen acrescido de extensor $(n=6)$, inseminação com sêmen fresco $(n=6)$ e não inseminadas $(n=6)$. A porcentagem de leucócitos polimorfonucleares (PMNs) encontrados na superfície endometrial e na análise histológica do endométrio foi confrontada com o resultado do exame microbiológico. A análise citológica não evidenciou diferença no número de células inflamatórias entre as cadelas não inseminadas (3,05 $\pm 1,74 \mathrm{PMNs})$ e as inseminadas com sêmen fresco $(3,55 \pm 1,51 \mathrm{PMNs})$, mas esses dois grupos diferiram do grupo inseminado com sêmen acrescido do extensor $(7,8 \pm 1,67 \mathrm{PMNs})(\mathrm{p}<0,05)$. Da mesma forma, na análise histológica, considerando-se três regiões uterinas observadas, verificou-se ausência de diferença entre os tratamentos, não inseminadas $(87,72 \pm 35,2 \mathrm{PMNs})$ e inseminadas com sêmen fresco $(122,97 \pm$ 43,31 PMNs), sendo que ambos diferiram das inseminadas com sêmen acrescido do extensor $(171,94 \pm 42,74 \mathrm{PMNs})(\mathrm{p}<0,05)$. A análise microbiológica evidenciou a presença de Staphylococcus $\mathrm{sp}$ ou Proteus sp, presentes em $45 \%(\mathrm{n}=8)$ das cadelas, independente do grupo no qual estavam inseridas. Verificou-se que o extensor para sêmen é um potente indutor de reação inflamatória local e que culturas positivas de swab endometrial podem ser obtidas de cadelas em estro, sem que as mesmas apresentem inflamação ou infecção.

Palavras-chave: cadela; inflamação; reprodução; sêmen 


\section{INTRODUCTION}

The arrival of mature and functionally competent spermatozoa at the site of fertilization is a phenomenon dependent on microevents that occurs in the uterus and uterine tube, where the interaction between spermatozoa and reproductive epithelium is important and may affect normal spermatozoa migration (Suarez, 1987).

Migration of polymorphonuclear neutrophilic granulocytes (PMNs) into the uterus is an event that occurs after natural mating or artificial insemination (AI) in mares and sows (Rozeboom et al., 1998; Troedsson et al., 2001). Troedsson et al. (2001) noticed an influx of PMNs into the uterus in mares after insemination using semen without bacteria, demonstrating that the process of inflammation may also occur without infection after coitus or inoculation of contaminated semen. They also confirmed that the equine semen activates complement, resulting in chemotaxis and migration of PMNs into the uterus, where they phagocyte not only bacteria, but also spermatozoa. Kotilainen et al. (1994) mentioned that artificial insemination (Al) using frozen semen resulted in a remarkable uterine inflammation in mares and they hypothesized that this event was due to the presence of egg yolk and glycerol in the extender.

This paper investigates the inflammation that may be present in the uterus of bitches following $\mathrm{Al}$ by evaluating of the endometrial cytology, histology and microbiology.

\section{MATERIAL AND METHODS}

Eighteen cross bred bitches and a stud dog, adults, with different ages were used for this trial (Table 1). The animals were submitted to clinical and laboratory examinations, and only those considered clinically normal and without abnormalities were considered for this experiment, after the agreement of the owners. The dog semen donor presented seminal sample free from microorganisms.

The bitches $(n=18)$ were randomized and divided into the following groups: insemination with fresh semen plus extender $(n=6)$, insemination with fresh semen $(n=6)$ and not inseminated $(n=6)$. The inseminations were performed 48 hours after estrus detection; each bitch was inseminated once, and 12 hours later they were subjected to ovaryhisterectomy to collect the samples.

After the beginning of proestrus, females were submitted to vaginal cytology and behavior analyses in the presence of the male, on alternate days, to detect the estrus beginning.

Semen was collected from a single donor by digital manipulation, according to Seager (1986). This male was also considered healthy after clinical and laboratory examinations. Semen was processed so that the ejaculate to be inseminated had a final concentration of $250 \times 10^{6}$ spermatozoa, diluted in $2 \mathrm{ml}$ of extender Tris-citrate (Tris -hidroximetil aminometano $^{\circledR}$, Merck, Darmstadt/ Germany) with $20 \%$ of egg yolk or seminal plasma. The insemination was performed by vaginal deposition.

Samples used for microbiological examination were collected from the distal third of the uterine horns and cultured for bacterial growth in blood agar plate. The cultures were incubated for 48 hours at $37^{\circ} \mathrm{C}$ and any bacterial growth was considered positive. For cytology, material was collected from the uterine body and horns (cranial portion). A sterile swab was rolled over the endometrial surface and then, over a clean microscope slide. Two hundred cells from each slide were counted (superficial endometrial cells and poly- 
Table 1 - Information about the bitches used in this trial

\begin{tabular}{cccl}
\hline Animal & $\begin{array}{c}\text { Age } \\
\text { (years) }\end{array}$ & $\begin{array}{c}\text { Weight } \\
(\mathrm{Kg})\end{array}$ & \multicolumn{1}{c}{ Reproductive history } \\
\hline 1 & 2 & 12 & Nulíparous, no others abnormalities \\
2 & 3 & 10 & Nuliparous, no others abnormalities \\
3 & 2 & 8 & Nuliparous, no others abnormalities \\
4 & 4 & 12 & Pluríparous (two pregnancies), without abnormalities \\
5 & 6 & 11 & Pluríparous (two pregnancies), without abnormalities \\
6 & 5 & 12 & Pluríparous (one pregnancy), without abnormalities \\
7 & 4 & 10 & Nulíparous, no others abnormalities \\
8 & 4 & 9 & Nulíparous, no others abnormalities \\
9 & 3 & 10 & Nulíparous, no others abnormalities \\
10 & 2 & 8 & Nulíparous, no others abnormalities \\
11 & 5 & 12 & Pluríparous (one pregnancy), with abnormal parturition \\
12 & 5 & 10 & Pluríparous (one pregnancy), without abnormalities \\
13 & 4 & 8 & Pluríparous (one pregnancy), without abnormalities \\
14 & 3 & 8 & Nulíparous, no others abnormalities \\
15 & 3 & 12 & Nulíparous, no others abnormalities \\
16 & 2 & 11 & Nulíparous, no others abnormalities \\
17 & 4 & 10 & Pluríparous (two pregnancies), without abnormalities \\
18 & 4 & 9 & Pluríparous (two pregnancies), one pregnancy with abnormal \\
& & & parturition (fetal dystocia) \\
\hline
\end{tabular}

morphonuclear leukocytes). For histological evaluation samples were collected from three regions of the uterus: the mid portion of the left and right horns and also the uterine body. The counting of inflammatory cells (PMNs) per $\mathrm{mm}^{2}$ was accomplished under light microscopy (Reichert PK 6,3 $\mathrm{mm}^{\circledR}$, Austria).

The analysis of variance and the Tukey-test were used to evaluate the effects of treatments on the number of inflammatory cells in endometrial cytology and histology, and compare this inflammatory response among the different parts of the uterus: BU (uterine body), LH (left horn), and $\mathrm{RH}$ (right horn). To verify the possibility of association between non parametric variable (positive or negative microbiological exam) and the parametric variable (number of PMNs), the Fisher exact test was performed. All data were analysed using the computer software SAS (1995).

\section{RESULTS}

Results were expressed as mean plus standard deviation ( \pm ). In the cytological study, there was no differ- ence between the mean number of PMNs in the females not inseminated (3.05 \pm 1.74 PMNs) and those inseminated with fresh semen (3.55 \pm 1.51 PMNs). However, the treatment that included extender was

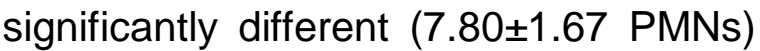
from the treatment in which the extender had not been used ( $3.55 \pm 1.51$ PMNs). Therefore, the use of extender resulted in higher means of PMNs (Figure 1). Spermatozoa were also seen in the inseminated bitches. Uterine histology showed that there was no significant difference between the number of $\mathrm{PMNs} / \mathrm{mm}^{2}$ among the different parts of the uterus: BU (body of the uterus), LH (left horn), $\mathrm{RH}$ (right horn), within the same treatment $(p<0.05)$. When we compared the same part of the uterus among the different treatments we verified that the number of PMNs from the bitches inseminated with fresh semen (BU: $155.50 \pm 82.80 \mathrm{PMNs} / \mathrm{mm}^{2}$, $\mathrm{LH}: \quad 94.83 \pm 15.32 \mathrm{PMNs} / \mathrm{mm}^{2}, \mathrm{RH}$ : 118.58 \pm 31.82 PMNs $/ \mathrm{mm}^{2}$ ) did not differ from those not inseminated (BU: $83,20 \pm 37.40 \mathrm{PMNs} / \mathrm{mm}^{2}$, LH: 87,84 $\pm 39.0 \mathrm{PMNs} / \mathrm{mm}^{2}, \quad \mathrm{RH}: \quad 92.13 \pm 29.22$ $\mathrm{PMNs} / \mathrm{mm}^{2}$ ). However, the highest number of PMNs $/ \mathrm{mm}^{2}$ were found in the 
Ribeiro et al. (2010)

Table 2 - Results of bacterial culture of canine uterine fluid. (Animals 1 to $6=$ inseminated with fresh semen plus extender; 7 to $12=$ inseminated with fresh semen; 13 to $18=$ no inseminated).

\begin{tabular}{ccc}
\hline Animal & Growth of microorganisms & Bacterial types isolated from uterus \\
\hline 1 & + & Staphyloccocus sp \\
2 & - & ---- \\
3 & + & Proteus $\mathrm{sp}$ \\
4 & + & Staphyloccocus sp \\
5 & - & ---- \\
6 & - & --- \\
\hline 7 & + & Staphyloccocus sp \\
8 & + & Proteus sp \\
9 & - & ---- \\
10 & - & ---- \\
11 & - & ---- \\
12 & - & Staphyloccocus sp \\
13 & + & Staphyloccocus sp \\
14 & +--- \\
15 & - & ---- \\
16 & - & - \\
17 & - & Staphyloccocus sp \\
18 & + &
\end{tabular}

bitches that received semen with the extender (BU: 167.38 \pm 36.26 PMNs/ $\mathrm{mm}^{2}$, LH: $142.68 \pm 44.59 \mathrm{PMNs} / \mathrm{mm}^{2}$, $\mathrm{RH}: 205.76 \pm 47.39 \mathrm{PMNs} / \mathrm{mm}^{2}$ ) (Figure 2). Therefore, the results found in histology were similar to those found in cytology. Besides, histology showed several normal structures of the canine endometrium during estrus: connective tissue, fibroblasts, mono and polimorphonuclear inflammatory cells, red blood cells, vessels, as well as the proliferation of endometrial glands and congestion of the connective tissue, as expected for a normal pattern of canine endometrial histology. Spermatozoa were seen inside the endometrial glands of inseminated bitches (photomicrographies of endometrial cytology and histology, in the Figures 3 and 4). Bacterial culture of the uterine fluid revealed growth of microorganisms (Staphyloccocus sp and Proteus sp) in eight $(45 \%)$ and there was no relationship to the treatment they had received (inseminated with fresh semen plus extender, with fresh semen or no inseminated) (Table 2). Statistical analysis showed independency between the results of the microbiological exam and endometrial cytology (Fisher Exact Test, $\mathrm{p}<0.93$ ).

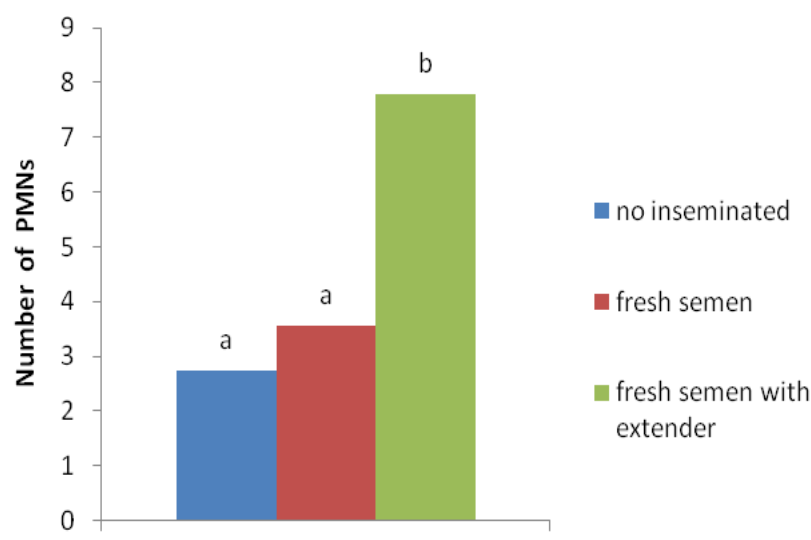

experimental groups

Figure 1 - Mean number of polymorphonuclear neutrophilic granulocytes (PMNs) found to each 200 counted endometrial cells, in the endometrial cytology of bitches not inseminated, with raw semen or with spermatozoa and extender. (The same capital letters did not differ, $\mathrm{P}<0.05 ; \mathrm{CV}=18.2 \%$ ).

\section{DISCUSSION}

The normal endometrial histological structures including connective tissue, fibroblast, inflammatory cells, red blood 


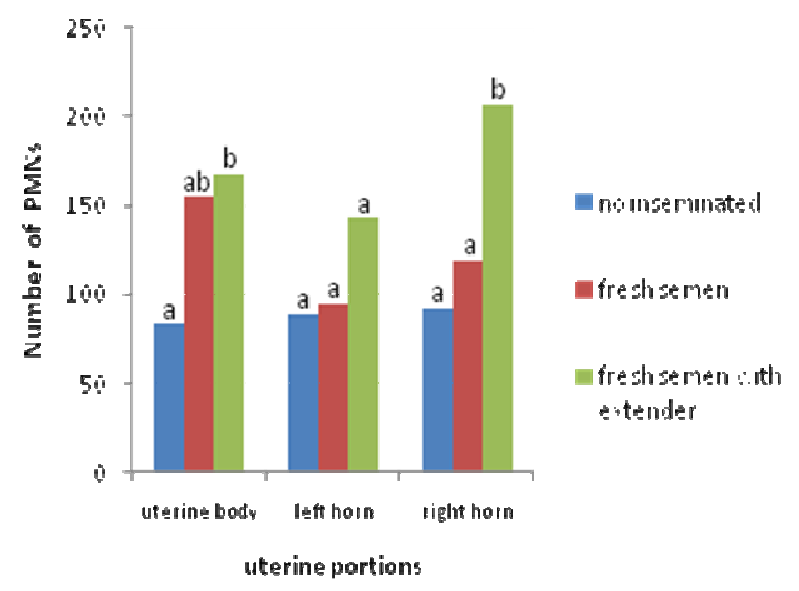

Figure 2 - Mean number of endometrial inflammatory cells (PMNs) per $\mathrm{mm}^{2}$, in the different portions of the uterus (uterine body; left horn; right horn), in bitches not inseminated, inseminated with fresh semen or with fresh semen with extender. The letters guide the comparison of the same uterine portion, in different treatments (The same capital letters did not differ, $\mathrm{P}<0.05 ; \mathrm{CV}=15.8 \%)$.

cells, endometrial glands and vessels, were also observed in this study, as well the low columnar endometrial luminal epithelium, as described by Watts and Wright (1998). According to these authors, neutrophils were the most common leucocytes observed during pro-estrus, estrus, diestrus and early pregnancy, but they related that was difficult quantify the numbers of leucocytes in sample collected from the bitch because many leucocytes had undergone degeneration. We believe that this report was concerned to collection technique that used the uterine flushing following by centrifugation. Degeneration was not observed in our study.

The analysis of uterine inflammation, quantified by PMNs counting, showed similar results in endometrial cytology and histology. The absence of statistical difference between data from bitches not inseminated and those inseminated with fresh semen, allow us to infer that the canine seminal plasma may act as an immunomodulator of the inflammatory reaction induced by spermatozoa. This event was previously described in swine, when researchers did not observe significative differences between the number of PMNs in the uterine lavage fluid of gilts inseminated with semen (spermatozoa plus seminal plasma), and the control group (not inseminated) (Rozeboom et al., 1999). According to Leblanc (2008), accumulation of intra-uterine fluid immediately after estrus related to the inflammation induced by semen can interfere with conception or maintenance of pregnancy, in mares. Thus, even when we compare different species, we believe that the biological events are similar, although in this study we did not investigate the ability of sperm to cause endometrial inflammation.

Kotilainen et al. (1994) mentioned that the use of semen with extender and without seminal plasma (frozen semen), produced a remarkable uterine inflammation in mares due to a few factors like the aggressive potential of the extender egg yolk and glycerol, liberation of enzymes by spermatozoa that were damaged during freezing, or by the use of a small volume of the inseminated fluid with high sperm concentration. Our data confirms the aggressive potential of the extender Tris-glucose with egg yolk and glycerol in the canine uterus due to the significative statistical difference observed. This last treatment presented the highest mean in the number of PMNs, both in endometrial cytology (7.80 \pm 1.67 PMNs) and histology (BU: 167.38 $\pm 36.26 \quad \mathrm{PMNs} / \mathrm{mm}^{2}$, LH: 142.68 $\pm 44.59 \quad \mathrm{PMNs} / \mathrm{mm}^{2}, \quad \mathrm{RH}$ : 205.76 $\left.\pm 47.39 \mathrm{PMNs} / \mathrm{mm}^{2}\right)$.

Tunon et al. (2000) have studied the distribution of T lymphocytes through immuno-histochemistry in different parts of the uteri of mares submitted to artificial insemination, and in their study more cells were found in the uterine body when compared to the uterine horns. Our results, however, revealed no difference between the inflammatory 


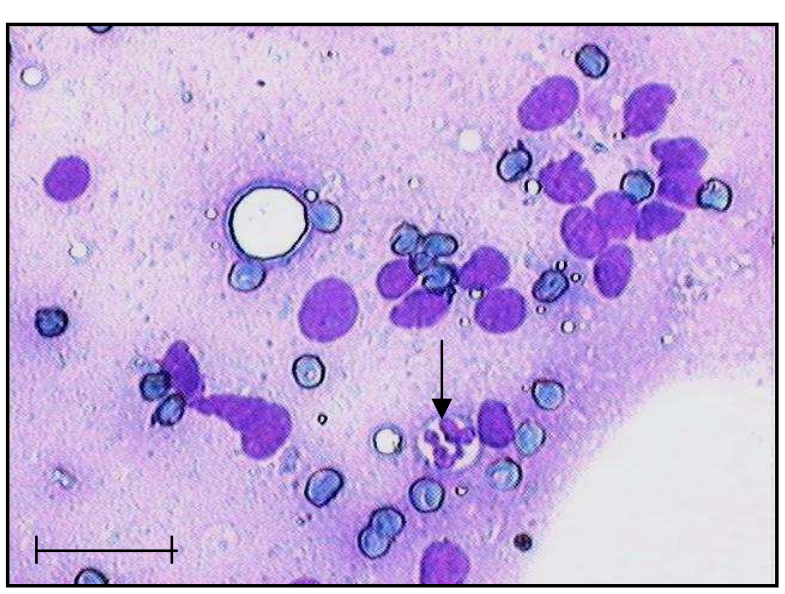

Figure 3 - Photomicrography of uterine cells (endometrial cytology) from a bitch inseminated with fresh semen with extender. Endometrial cells with large oval and basophilic nucleus, red blood cells and polymorphonuclear neutrophilic granulocytes (PMN), which were counted (arrow). Scale bar represents $25 \mu \mathrm{m}$. Rosenfeld stain.

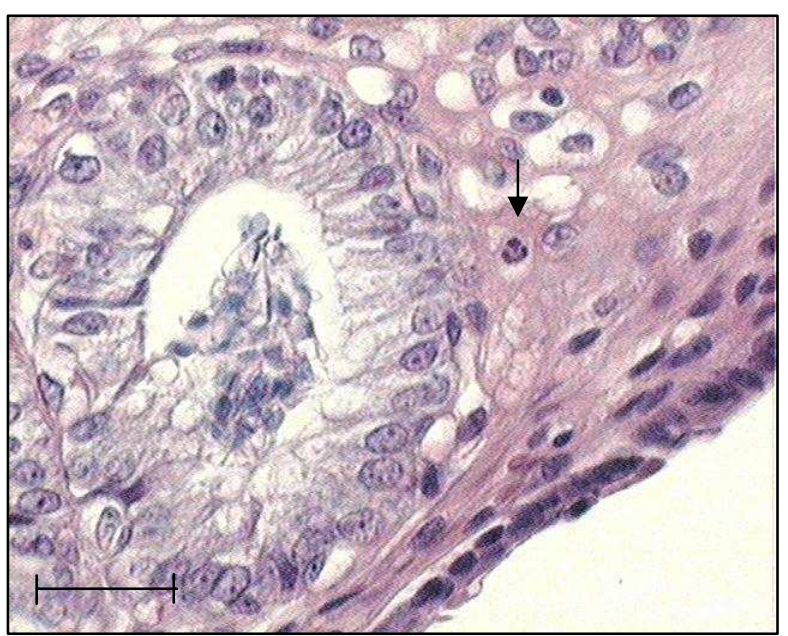

Figure 4 - Photomicrography of a segment of uterine body (endometrial histology) from a bitch inseminated with fresh semen. Large number of spermatozoa inside the endometrial gland and polymorphonuclear neutrophilic granulocytes (PMN), which were counted (arrow). Scale bar represent $25 \mu \mathrm{m}$. Hematoxilin-eosin stain.

reaction found in the uterine body and horns. In our opinion, this has occurred because the fluid used for insemination has been deposited in the cranial vagina, and thus it was equally distributed into the uterus, avoiding its accumulation in some specific part of the organ, differing from what happened in mares which received semen by intra uterine insemination.

Some researchers have been speculating that the bacterial contamination and not the semen, is the cause of uterine inflammation after coitus or artificial insemination. Taking this into account, Rozeboom et al. (1999) and Troedsson et al. (2001) have proved that high percentage of PMNs can be found in the uterus of healthy mares and gilts submitted to artificial insemination using semen without bacteria. Watts et al. (1996) concluded in their study that a large number of bitches in estrus had positive microbial cultures of uterine fluid. These observations were similar to ours. These authors described that the diagnosis of endometritis requires the presence and isolation of bacteria and additional clear evidence of disease such as an increase in leucocytes in endometrial cytological samples and purulent cervical discharge. In agreement we verified independence between the results of culture (positive or negative) and the number of PMNs found in endometrial cytology. We also found bitches with high number of PMNs and negative culture and others with low number of PMNs and positive culture. Hence, the magnitude of uterine inflammation, characterized by PMNs presence, had no correlation with the culture results, but with the treatments that the animal was submitted (insemination with fresh semen plus extender).

\section{CONCLUSION}

Canine seminal plasma has an immunomodulatory action on the uterine inflammation in response to the irritative action of spermatozoa. Tris glucose with egg yolk and glycerol, as a semen extender, is a potent inductor of uterine inflammation. 
Microorganisms can be found in the uterus of estrus bitches, indicating a natural microbiota in this stage of the estral cycle, not related to endometrial inflammation or uterine infection.

\section{AKNOWLEDGEMENT}

The authors thank Professor Gener Tadeu Pereira for advising on statistical analysis; Department of Animal Reproduction, Animal Morphology and Physiology and Animal Pathology. The present study was supported by FAPESP and CAPES, Brazil.

\section{REFERENCES}

KOTILAINEN, T.; HUHTINEN, M.; KATILA, T. Sperm-induced leukocitosys in the equine uterus. Theriogenology, v.41, p.629-623, 1994.

LEBLANC, M.M. When to refer an infertile mare to a theriogenologist. Theriogenology, v.70, n.3, p.421-429, 2008.

ROZEBOOM, K.J.; TROEDSSON, M.H.T.; CRABO, B.G. Characterization of the uterine leukocyte infiltration in gilts after artificial insemination. Journal of Reproduction and Fertility, v.114, n.2, p. 195-199, 1998.

ROZEBOOM, K.J.; TROEDSSON, M.H.T.; MOLITOR, T.W. et al. The effect of spermatozoa and seminal plasma on leukocyte migration into the uterus of gilts. Journal of Animal Science, v.77, n.8, p.2201-2206, 1999.
SEAGER, S.W.J. Artificial insemination in dogs. In: BURKE,T.J. Small Animal Reproduction and Fertility - A clinical approach to diagnosis and treatment. Philadelphia: Lea and Febiger, 1986, p.207-217.

SUAREZ, S.S. Sperm transport and motility in the mouse oviduct: observations in situ. Biology of Reproduction, v.36, n.1, p.203-210, 1987.

TROEDSSON, M.H.T.; LOSET, K.; ALGHAMDI, A.M. et al. Interaction between equine semen and the endometrium: the inflammatory response to semen. Animal Reproduction Science, v.68, n.3, p.273-278, 2001.

TUNON, A.M.; KATILA, T.; MAGNUSSON, R. et al. T-cell distribution in two different segments of the equine endometrium 6 and 48 hours after insemination. Theriogenology, v.54, n.6, p.835$841,2000$.

WATTS, J.R.; WRIGHT, P.J.; WHITHEAR, K.C. Uterine, cervical and vaginal microflora of the normal bitch throughout the reproductive cycle. Journal of Small Animal Practice, v.37, n.2, p. 54-60, 1996.

WATTS, J.R.; WRIGHT, P.J . Endometrial cytology of the normal bitch throughout the reproductive cycle. Journal of Small Animal Practice, v.39, n.1, p.2-9, 1998. 